\title{
NAUKA A WIARA W OKRESIE POPOZYTYWISTYCZNYM
}

\section{Czego uczy historia?}

Zwykle o zagadnieniu nauka a wiara teologowie myślą jako o dość peryferyjnym zagadnieniu $\mathrm{z}$ dziedziny apologetyki religijnej. Z dziedziny apologetyki religijnej, gdyż należy „wykazać”, że zarzut niezgodności religii z nauką jest fałszywy, czyli obronić religię przed pozornie uzasadnionymi, lub nieuczciwie interpretowanymi roszczeniami nauki. Jest to zagadnienie peryferyjne, gdyż zasadniczo nie wnosi ono nic istotnego do samej teologii; choć tylko dość peryferyjne, ponieważ jednak dla wielu ludzi może stanowić poważną przeszkodę na drodze do wiary religijnej.

Pogląd taki nie tylko skrajnie upraszcza cały problem, lecz jest po prostu fałszywy. Wymownie świadczy o tym przykład z historii. Na początku $1616 \mathrm{r}$. Swięte Oficjum w Rzymie zleciło komisji, złożonej z jedenastu teologów, zbadanie zasadności oskarżenia, wniesionego przeciw Galileuszowi. W ciągu kilku dni werdykt był gotów i 3 marca 1616 r. został wydany dekret, zawieszający dzieło Kopernika De revolutionibus orbium coelestium, dopóki nie zostanie poprawione (donec corrigatur). Wprawdzie w tym dekrecie nazwisko Galileusza nie zostało wymienione, ale nie ulegało wątpliwości, że dekret był wymierzony przeciwko niemu. Galileusz, przeczuwając taki obrót sprawy, już wcześniej napisał swoją „teologiczną obronę” w postaci Listu do Księżnej Krystyny ${ }^{1}$. W liście tym twórca nowej nauki, opierając się na autorytecie Ojców Kościoła, zwłaszcza św. Augustyna, przedstawił (mówiąc dzisiejszym językiem) zasady hermeneutyki biblijnej i przy ich pomocy dowodził, że nie może być sprzeczności pomiędzy astronomią a prawdami wiary, gdyż — z jednej strony — astronomia nie jest przedmiotem Objawienia, a - z drugiej strony - tekst biblijny niekiedy dopuszcza wiele różnych interpretacji. Teologia Galileusza nie zosta-

${ }^{1}$ Letter to Madama Christina, [w:] S. D r a k e, Discoveries and Opinions of Galileo, New York 1957, s. $175-216$. 
ła wzięta pod uwagę przez teologów-ekspertów i późniejszy bieg wydarzeń doprowadził do procesu i potępienia Galileusza w $1633 \mathrm{r}^{2}$

Spójrzmy na tę sprawę z dzisiejszej perspektywy. Teologowie-eksperci, w istocie odpowiedzialni za potępienie Galileusza, zostaliby uznani przez każdą dzisiejszą „komisję kościelną” za głoszących niedopuszczalne poglądy. Współczesna bowiem „ogólnie przyjęta interpretacja” stała się bardzo podobna do tej, o jaką walczył Galileusz w Liście do księżnej Krystyny. Ależ nie! Teologowie nigdy nie sięgnęli do argumentów przytaczanych przez Galileusza. To oni sami, na nowo, trudną drogą analiz porównawczych, krytyki tekstu, metody form, itp., odkryli w zasadzie to samo (choć z pewnością głębiej, uczeniej i — dla nich — bardziej przekonywająco), co Galileusz głosił, kierując się zdrowym rozsądkiem, znajomością nauki i radami kilku przyjaznych teologów ${ }^{3}$.

Przykład ten wymownie ukazuje, w jakim stopniu konfrontacja z nauką może być dla teologii czynnikiem postępu. „Sprawa Galileusza” nie była pod tym względem wyjątkiem. Dopiero dziś i dopiero niektórzy teologowie zaczynają wyciągać wnioski ze „sprawy Darwina”, coraz bardziej rozumiejąc, jak czynnik czasu i rozwoju może zmienić całą perspektywę teologiczną ${ }^{4}$.

Nie jest więc prawdą, że zagadnienie nauka a wiara należy do ubocznych problemów apologetyki. Od czasów kardynała Newmana wiadomo, że nawet dogmaty wiary, w swojej warstwie interpretacyjnej, podlegają ewolucji. Wszystko wskazuje na to, że jednym z najpotężniejszych czynników tej ewolucji, i w ogóle elementem postępu w teologii, jest nieustannie dokonująca się (niezależnie od woli teologów) konfrontacja przekonań religijnych z przekonaniami o świecie i jego „funkcjonowaniu”. Ale te ostatnie przekonania zawsze były kształtowane przez nauki danej epoki. Nasza epoka dodała tylko do tego procesu niespotykany przedtem postęp nauk i niespotykaną przedtem sugestywność w kształtowaniu przez naukę postaw bardzo wielu ludzi.

\section{Dziedzictwo pozytywizmu}

Przekonanie, że problem „nauka a wiara” należy do wąsko rozumianych apologetycznych zadań teologii, utrwaliło się w okresie dominacji neopozytywizmu w rozumieniu nauki i jej metody. Utożsamienie przez neopozytywistów sensowności z empirycznością wyeliminowało wypowiedzi religijne (i teologiczne) z rodziny języków sensownych i nic dziwnego, że bardzo ważnym — ale

\footnotetext{
${ }^{2}$ Opis tych wydarzeń por.: S. D ra ke, Galileo: A Biographical Sketch, [w:] Galile o-Man of Science, red. E. M cMulli n, New York-London 1967, s. 52-66.

${ }^{3} \mathrm{O}$ teologicznym aspekcie „sprawy Galileusza” por.: O. Pe d e r s e n, Galileo and the Council of Trent, „Studi Galileiani” vol. 1 nr 1, Specola Vaticana 1983.

${ }^{4}$ Warto tu wymienić teilhardowskie i whiteheadowskie kierunki w teologii, które wyciągają być może nawet zbyt radykalne — wnioski z tej lekcji historii.
} 
tylko apologetycznym - zadaniem dla teologów stało się obronienie swojej dyscypliny przed zarzutem mówienia o niczym lub nawet gorzej - mówienia tylko pozornie. Nawet ludzie, którzy nigdy nie słyszeli o Kole Wiedeńskim i mieli niewiele wspólnego z jakąkolwiek filozofią, dali sobie wmówić, że doświadczenie (i to tylko zmysłowe) oraz rozumienie to dwa pojęcia, jeśli nie identyczne, to w każdym razie praktycznie nierozróżnialne.

Co więcej, wpływ pozytywizmu, i potem neopozytywizmu, w pierwszej połowie naszego stulecia był tak ogromny, że nawet jego przeciwnicy nieświadomie przyjmowali - przynajmniej w niektórych sprawach — jego sposób myślenia i argumentacji. Dotyczyło to przede wszystkim zagadnień metodologicznych. Pozytywizm miał wówczas, praktycznie rzecz biorąc, monopol na metodologię nauk i każdy, kto wkraczał w tę dziedzinę, chcąc nie chcąc czerpał z pozytywistycznych dokonań. Dotyczyło to również teologów i filozofów chrześcijańskich w momencie, gdy sięgali oni po argumenty metodologiczne, by bronić sensowności wypowiedzi nie opartych bezpośrednio na doświadczeniu (zmysłowym). Zgadzali się oni — przyznając pod tym względem rację neopozytywistycznej metodologii - na dychotomię zdań empirycznych i zdań nie opartych na doświadczeniu, a cały swój kunszt interpretacyjny skupiali na próbie wykazania, że to, co nieempiryczne, nie musi być bezsensowne. Nic dziwnego, że efektem tego rodzaju wysiłków były „metodologie rozdziału”: nauki, z jednej strony, a religia (teologia, filozofia), z drugiej strony, znajdują się na różnych, nigdzie nie przecinających się płaszczyznach poznawczych. To, co jednej stronie wydaje się bezsensem, dla drugiej strony jest tylko metodologiczną odmiennością.

Taką strategię stosowali (i nadal stosują) myśliciele neotomistyczni naszego stulecia (w sprawach metodologicznych może najwięcej zawdzięczają oni Maritainowi), nie zdając sobie sprawy z tego, że walczą bronią przynajmniej w połowie przygotowaną przez pozytywistów.

Dziś okres panowania neopozytywizmu w filozofii nauki należy do przeszłości. Utożsamienie empiryczności z sensownością i doktrynę o ścisłej dychotomii zdań empirycznych i teoretycznych włożono pomiędzy metodologiczne mity. Kurczowe trzymanie się ideologii „metodologicznego rozdziału” jest dziś anachronizmem. Ideologia ta nie tylko opiera się na fałszywych (ale szczęśliwie już przezwyciężonych) założeniach, ale jest gorzej niż nieskuteczna: zamiast bronić wypowiedzi religijnych (teologicznych, filozoficznych), wyłącza je poza obszar ogólnie dziś przyjmowanych zasad metodologicznych.

Oczywiście nie ma powrotu do epoki przedpozytywistycznej. Metodologia nauk (a także metodologia filozofii) poczyniły ogromne postępy, których nie można ignorować. Rozpoznanie swoistości metodologicznych nauk empirycznych i innych rodzajów poznania zostało wypracowane, pewne rozróżnienia weszły na stałe do arsenału środków metodologicznych. Zapominanie o tym lub przekreślanie tego oznaczałoby metodologiczną anarchię. Niebezpieczeń- 
stwo zaczyna się dopiero wtedy, gdy metodologiczne reguły traktuje się jak niepodważalne dogmaty. Metodologia jest tylko narzędziem, a jeżeli ma istnieć postęp, to narzędzia muszą się doskonalić.

\section{Zwrot ku filozofii}

W latach 80-tych świat nauki jakby odetchnął, uwolniwszy się spod jarzma pozytywizmu. Zadziałały tu dwa czynniki: Po pierwsze, począwszy od słynnej pracy Quine'a $O d w u$ dogmatach empiryzmu ${ }^{5}$, zaczęto skutecznie wykazywać fałszywość neopozytywizmu zarówno jako filozofii nauki, jak i jako bardziej ogólnego stanowiska filozoficznego. Po drugie, rozwój współczesnych teorii fizycznych wyłamał się spod reguł ustalonych przez neopozytywistyczną metodologię. Niewątpliwie obydwa te czynniki współdziałały ze sobą, ale wydaje mi się, że czynnik drugi odegrał znaczniejszą rolę, w każdym razie gdy idzie o przekonanie świata nauki, że ciasny empiryzm jest nie do utrzymania. Nie należy jednak mieć złudzeń: ogromne masy technicznej (i nie tylko) inteligencji są nadal pod przemożnym wpływem poglądów, wywodzących się z pozytywizmu. Statystyczne badania środowisk uniwersyteckich z pewnością nie wykazałyby ustąpienia wpływów neopozytywistycznych, ale też o profilu nauki nie decyduje statystyka, lecz pewna, bardzo wybrana elita, która jest odpowiedzialna za to, co będzie się robić i jak będzie się myśleć w następnej epoce. A właśnie ta elita coraz bardziej odchodzi od stylu pozytywistycznego myślenia.

Wiążą się $\mathrm{z}$ tym także pewne niebezpieczeństwa. Jednym $\mathrm{z}$ nich jest uprawianie filozofii nauki na własną rękę przez przedstawicieli nauki, nie będących zawodowymi filozofami. Często jest to filozofia kiepskiego gatunku, sprowadzająca się do ponownego „odkrywania” rzeczy już dawno znanych w filozofii i wyrażania ich dość prymitywnym językiem. Niestety łączy się to z pewnym totalitaryzmem nauki (niewątpliwe dziedzictwo pozytywistycznego okresu), tzn. z pogardliwym lekceważeniem osiągnięć wypracowanych przez filozofię (lub niekiedy przez teologię) niezależnie od „kontekstu współczesnych nauk”. Nie należy jednak tragizować. Wydaje się, że jest to cena, którą warto płacić za ogromną szansę, jaką niesie ze sobą otwarcie się na pozaempiryczne obszary racjonalności. Tym bardziej, że „wejście” profesjonalnych naukowców do filozofii otwiera zupełnie nowe możliwości. Idzie nie tylko o to, że ludzie wyposażeni w duży zasób wiedzy o świecie często potrafią oryginalnie spojrzeć na stare problemy, a niekiedy dostrzec ich nieoczekiwane aspekty, które dotychczas uchodziły uwadze (wiele przykładów takiej świeżości spojrzenia można by cy-

${ }^{5}$ W zbiorze jego prac: $Z$ punktu widzenia logiki, Warszawa 1969 , s. $35-70$.

${ }^{6}$ Klasycznym tego przykładem jest książka: P. C. W. D avies, God and the New Physics, London 1983. 
tować), ale przede wszystkim o to, że niekiedy zapoczątkowują oni zupełnie nowe rozdziały filozoficznych dociekań. Na naszych oczach rodzą się nowe problemy, wygenerowane przez współczesne teorie naukowe, których filozoficzną doniosłość dopiero zaczynamy rozumieć (np. ewolucja i powstawanie struktur w stanach odległych od równowagi, zagadnienie sztucznej inteligencji, rola strukturalnej stabilności w filozofii nauki, itp.). To zainteresowanie świata nauki filozofią pociąga za sobą wzrost jego zainteresowań religią i teologią.

Nie należy jednak łudzić się, że „trudne czasy” dla teologii skończyły się i teraz już wszystko będzie szło ku zgodnej syntezie. Dzieje ludzkiej myśli zawsze są napiętnowane różnicami poglądów i ostrymi polemikami. Wszystko wskazuje na to, że na horyzoncie pojawia się nowe zagrożenie dla teologii i religii. Nauka zawsze wykazywała tendencje totalitarystyczne („,wszystko da się wyjaśnić naukowo"); teraz - uwolniona od pozytywistycznej niechęci do metafizyki - sama zaczyna stawać się swoistą metafizyką. Coraz więcej fizyków zaczyna wierzyć w to, że nauka (wkrótce!) dostarczy ostatecznego wyjaśnienia istnienia świata. Najnowsze teorie fizyczne i kosmologiczne nie tylko ukazują, jak prawa fizyki mogły spowodować zaistnienie świata, ale coraz częściej zadają sobie pytanie, skąd wzięły się prawa fizyki. Jednym z możliwych wyjaśnień byłoby wykazanie, że istnieje tylko jedna możliwa teoria fizyczna, wyjaśniająca wszystkie zjawiska (tak zwana już z góry „theory of everything”). Nie wszyscy zdają sobie sprawę $z$ tego, że niemal każde słowo w poprzednim zdaniu wymaga gigantycznego wysiłku myślowego: Co to znaczy „wyjaśnić”? W jakim sensie „wszystkie” zjawiska? W jakim znaczeniu ,jedynie możliwa” teoria? Jak można wykazać, że taka teoria jest ,jedyna”? „Jedyna” przy danym zbiorze założeń, czy „,jedyna” w ogóle? Czy to ostatnie ma jakikolwiek sens? Nie tu miejsce na obszerniejsze omawianie tej problematyki ${ }^{7}$; chcę ją jedynie zasygnalizować i zwrócić uwagę na fakt, iż — moim zdaniem - w niedalekiej przyszłości będzie ona stanowić bardzo chwytliwy argument rozmaitych antyreligijnych ideologii.

\section{Inicjatywy}

Powstaje pytanie o reakcję przedstawicieli religii i teologów na przedstawiony powyżej zwrot, jaki dokonał się w świecie nauki. Próba podania bardziej wyczerpującej odpowiedzi na to pytanie wymagałaby odrębnego studium. W dalszym ciągu ograniczę się jedynie do kilku faktów i kilku refleksji dotyczących sytuacji w Kościele katolickim.

${ }^{7}$ Mówiłem na ten temat na Drugim Europejskim Sympozjum „Nauka a Wiara” w Entschede (marzec 1988); tekst odczytu został opublikowany w „Studiach Interdyscyplinarnych” 2: 1988. 
W Kościele katolickim granicę epok na pewno stanowi II sobór watykański. Data tej granicy mniej więcej zbiega się z początkiem schyłku filozofii neopozytywistycznej. Ale sobór był zbyt zajęty sprawami ogólnoludzkimi i wewnątrzkościelnymi, by zwrócić uwagę na ten fakt. Zresztą zagadnienia związane z nauką mało interesowały Ojców soboru. Nie licząc wypowiedzi dotyczących społecznych skutków rozwoju nauki, czy jeszcze bardziej techniki, w dokumentach soborowych znajduje się jedynie dość ogólnikowa wzmianka o autonomii, jaką powinna cieszyć się nauka ${ }^{8}$. Dziś, z perspektywy czasu, wyraźnie widać pewien uboczny skutek reformy soborowej, który źle przysłużył się zagadnieniu nauka a wiara: położenie nacisku na sprawy duszpasterskie, zbyt wąsko zrozumiane przez tych, którzy uchwały soboru wprowadzali w życie, spowodowało odwrócenie uwagi zarówno hierarchii, jak i w ogóle duchowieństwa od związków religii z nauką, co pociągnęło za sobą (na całym świecie) znaczne zmniejszenie liczby duchownych, posiadających wyższe wykształcenie w dziedzinie nauk przyrodniczych, a tym bardziej uprawiających je czynnie. Zwiększyło to jeszcze, już i tak duży, dystans między „światem religii” a „światem nauki".

Ponad dwadzieścia lat, jakie dzieli nas od soboru, jest długim okresem i nic dziwnego, że w interesującej nas kwestii nie wystarczy sięgać po inspiracje do soborowych dokumentów. Problematyka „nauka a wiara” jest bardzo wrażliwa na zmiany, jakie niesie współczesność.

Na polecenie papieża Jana Pawła II, we wrześniu 1987 r. w Castel Gandolfo, odbyło się międzynarodowe sympozjum na temat: „Our Knowledge of God: Physics, Philosophy, and Theology”. Oficjalnym motywem sympozjum była trzechsetletnia rocznica wydania drukiem Matematycznych zasad filozofii przyrody Izaaka Newtona. Spotkanie zgromadziło dwudziestu specjalistów z dziedziny nauk empirycznych (głównie fizyki), historii i filozofii nauki oraz teologii (zarówno katolickiej, jak i protestanckiej); wyraźnie miało ono charakter zapoczątkowujący pewien nowy kierunek badań interdyscyplinarnych. Tom, będący uwieńczeniem tego Sympozjum ${ }^{9}$, otwiera słowo Papieża do uczestników spotkania. Myśli poruszone w tym wystąpieniu są doniosłe i z pewnością zasługują na obszerniejszy komentarz. O wykorzystaniu współczesnych nauk przyrodniczych w teologii papież mówił między innymi: „Sprawa jest paląca. Osiągnięcia współczesnej nauki rzucają teologii wyzwanie, sięgające znacznie głębiej niż wprowadzenie arystotelizmu w Zachodniej Europie w XIII wieku"10. Jeżeli uświadomić sobie rolę, jaką, począwszy od XIII stulecia, filozofia Arystotelesa odegrała w myśli chrześcijańskiej, to pełniej ukazuje się dramatyczność sytuacji, o której mówił papież.

${ }^{8}$ Por. konstytucja soborowa Gaudium et Spes, 36.

9 Physics, Philosophy, and Theology: A Common Quest for Understanding, red. R. J. R u ss e I, W. R. St o e ger, G. V. Coy n e, Vatican Observatory - Vatican City State 1988.

${ }^{10}$ Tamże, s. M 12. 
Waga tego rodzaju oficjalnych wystąpień jest ogromna. Mogą one zwiastować - zwłaszcza w dłuższej skali czasowej - pewien zwrot w stosunku Kościoła do nauk empirycznych. Ale żadne oficjalne deklaracje nie odniosą spodziewanego skutku, jeżeli nie będą im towarzyszyć „,inicjatywy oddolne”, tzn. czynne zainteresowanie naukowców, filozofów i teologów ich wspólną problematyką; przy czym w pierwszy plan wysuwa się konieczność wzajemnego zrozumienia. Niczym nie dającym się zastąpić warunkiem tego zrozumienia jest wykształcenie przyrodników, którzy byliby teologami i teologów, którzy byliby w stanie czynnie uprawiać nauki. Spotkania specjalistów, nie będących specjalistami w dziedzinie drugiej strony, dotychczas nie przyniosły prawie żadnych rezultatów; często wręcz pogłębiały istniejące nieporozumienia, a nierzadko obie strony w ogóle nie były w stanie zrozumieć siebie nawzajem (co gorsze, $\mathrm{z}$ reguły nie będąc tego świadome).

Sądzę, że pewną okolicznością łagodzącą ten stan rzeczy jest fakt, że dobra znajomość historii zagadnienia „nauka a wiara” — jak wskazuje na to doświadczenie - może przynajmniej w części zastąpić „bycie specjalistą w dwu dziedzinach równocześnie".

\section{Tendencje doktrynalne}

W poprzednich częściach wykładu mówiłem raczej o zewnętrznych tendencjach i inicjatywach w dziedzinie „nauka a wiara”. Pora naszkicować — bodaj w największym skrócie - merytoryczne osiągnięcia w tej dziedzinie. Celowo pominę cytowanie autorów i publikacji: musiałoby być ono albo zniekształcająco niekompletne, albo rozdęłoby wykład poza wszelkie dopuszczalne rozmiary (w przypisach pozwolę sobie wspomnieć jedynie o (nielicznych) pozycjach z tej dziedziny, jakie ostatnio ukazały się w Polsce).

Jak już zaznaczyłem wyżej, ważną rolę w problematyce „nauka a wiara” odgrywają badania historyczne. Ukazują one ścisłe związki genetyczne pomiędzy filozofią i teologią starożytności i średniowiecza a powstaniem nauk empirycznych w XVII wieku. Związki te nie ograniczają się tylko do „kontekstu odkrycia”, lecz niekiedy sięgają bardzo głęboko do samej struktury naukowych teorii. Warto dodać, że badania nad historią nauki odegrały niemałą rolę w likwidacji pozytywizmu. Historycy nauki znacznie wcześniej niż filozofowie nauki zrozumieli, że nauka nigdy nie stosowała się do reguł wymyślonych przez pozytywistów.

Są również prowadzone badania, które ukazują zależności, idące niejako w drugą stronę, a mianowicie wpływ „naukowego obrazu świata”, jaki obowiązuje w danej epoce, na interpretację prawd religijnych, a niekiedy nawet na sformułowania dogmatyczne ${ }^{11}$. Dość dobrze zostały zbadane dzieje wzajemnych oddziaływań teologii i nauk przyrodniczych, we wczesnym okresie istnie- 
nia tych ostatnich, na terenie Wysp Brytyjskich. Znacznie gorzej sprawa wygląda, gdy idzie o ten sam problem na Kontynencie. I prawie zupełnie brak opracowań historycznych problemu ,nauka a wiara” w okresie podarwinowskim.

Zgodnie z tym, co mówiłem we wstępie, zagadnienie „nauka a wiara” przestaje być wąsko rozumianym problemem dla apologetyki i coraz bardziej wnika do najważniejszych traktatów teologicznych. Nie jest zaskoczeniem, że są to przede wszystkim traktaty dotyczące natury Boga, jego stosunku do świata i koncepcji stworzenia. Metodologia współczesnej fizyki nauczyła nas wiele na temat stosunku naukowych modeli do rzeczywistości. Jeżeli nasze poznanie Boga jest analogiczne - jak głosi tradycyjna teza filozoficzna — to czemu nie mamy czerpać analogii z tej nowej dziedziny poznania; tym bardziej, że nowe „modele Boga” (określenia tego używa się coraz częściej), jak się okazuje, są w stanie przybliżyć te aspekty Bożej rzeczywistości, wobec których dawne próby pozostawały bezsilne ${ }^{12}$.

Problem czasu był niemal od zawsze głęboko uwikłany w zagadnienia teologiczne. Stosunek czasu do wieczności jest klasycznym tematem teologicznym i nasze koncepcje wieczności istotnie zależą od naszego rozumienia czasu. Bez przesady można powiedzieć, że współczesna fizyka (wraz z astronomią i kosmologią) oraz biologia na nowo odkryły „czasowy wymiar” rzeczywistości. Punktem wyjścia do współczesnych kierunków teologicznych stało się przemyślenie od nowa chrześcijańskiej antropologii w świetle ukazywanej przez nauki ewolucji świata. Ogromną rolę odgrywają tu najnowsze osiągnięcia fizyki procesów nieodwracalnych, które pozwalają zrozumieć emergencję struktur we Wszechświecie i wzrost informacji w układach otwartych. W oczach dzisiejszej nauki ewolucja nie jest mechanicznym odtwarzaniem programu zawartego w warunkach początkowych, lecz stanowi proces prawdziwie twórczy. Teologowi łatwiej dziś zrozumieć, że ewolucja i kreacja mogą być pojmowane jako dwa aspekty tego samego.

Tajemnica Wcielenia - włączenie się Logosu w ewolucyjny proces świata, domaga się nowych pogłębień interpretacyjnych. To z kolei organicznie wiąże się z problemem zła, grzechu i Odkupienia. Teologowie eksplorujący tę dziedzinę badań, pokazali, że tradycyjne traktaty teologiczne mogą zostać istotnie wzbogacone przez „wzięcie na serio” tego, co o rzeczywistości mówią nauki przyrodnicze ${ }^{13}$.

Jeszcze jeden temat głęboko teologiczny — samo istnienie nauk. Dlaczego świat da się badać? Dlaczego wymyślone przez człowieka (czy może odkryte) struktury matematyczne tak skutecznie przyczyniają się do ujawniania ukry-

\footnotetext{
${ }^{11}$ Por. N. M. Wild ie rs, Obraz świata a teologia, Warszawa 1985.

12 Por. I. G. B a rb o u r, Mity, modele, paradygmaty, Kraków 1984. Znak.

${ }^{13}$ Kwestię tę porusza A. Peacocke w książce przygotowywanej do druku przez wydawnictwo
} 
tych struktur samego świata? Jak wiadomo, pytania te nurtowały Einsteina i do dziś nie dają spokoju wielu naukowcom i filozofom nauki. Stanowią one także źródło głębokich refleksji teologicznych. Streszcza je krótko, ale jakże głęboko, zdanie wypowiedziane przez Olafa Pedersena w prywatnej rozmowie: „To, że Chrystus jest Logosem, oznacza, że immanencja Boga w świecie jest racjonalnością świata". Starożytni Grecy mówili o zasadzie porządku świata czy wręcz o jego duszy lub rozumie i rozum ten nazywali Logosem. Dziś mówimy o badalności lub racjonalności świata. Ale jest to w gruncie rzeczy ta sama Tajemnica - Tajemnica, przed którą staje zarówno teologia, jak i współczesna filozofia nauki.

FAITH AND SCIENCE IN THE POSTPOSITIVISTIC PERIOD

\section{Summary}

It is argued that the problem commonly known as the faith and science problem is interesting not only because of its apologetic aspects, but also because of its manifold contributions to better understanding some fundamental tenets of Christian religion. After the fall of the logical positivism, the „world of science” shows a growing interest in philosophy and seems to be more open for a dialogue with theology. Some conditions for such a dialogue, on both sides, and actual tendencies are explored. 